\title{
Multivariate Diversity Analysis for Grain Micronutrients Concentration, Yield and Agro-morphological Traits in Pearl millet (Pennisetum glaucum (L) R. Br.)
}

\author{
Mithlesh Kumar ${ }^{1 *}$, Kirti Rani ${ }^{2}$, B. C. Ajay ${ }^{2}$, M. S. Patel ${ }^{3}$, K. D. Mungra ${ }^{4}$ and M. P. Patel ${ }^{5}$ \\ ${ }^{1}$ College of Agriculture, S.D. Agricultural University, Tharad, Gujarat 385565, India \\ ${ }^{2}$ Directorate of Groundnut Research (DGR), Junagadh, Gujarat 362001, India \\ ${ }^{3}$ Centre for Crop Improvement (CCI), S.D. Agricultural University, \\ S.K.Nagar, Gujarat 385506, India \\ ${ }^{4}$ Pearl millet Research Station (PMRS), Junagadh Agricultural University, \\ Jamnagar, Gujarat 361006, India \\ ${ }^{5}$ Pulses Research Station, S.D. Agricultural University, S.K.Nagar, Gujarat 385506, India
}

*Corresponding author

\section{A B S T R A C T}

\begin{tabular}{l} 
K e y w o r d s \\
Multivariate, \\
diversity analysis, \\
diversity index, \\
correlation, \\
association analysis, \\
cluster analysis, \\
principal \\
component, grain \\
micronutrients, \\
pearl millet, \\
UPGMA \\
\hline $\begin{array}{l}\text { Article Info } \\
\text { Accepted: } \\
15 \text { February } 2020 \\
\text { Available Online: } \\
\text { 10 March } 2020\end{array}$
\end{tabular}

\begin{abstract}
Micronutrient malnutrition resulting from the dietary deficiency of important minerals such as Iron (Fe), Zinc $(\mathrm{Zn})$, Copper $(\mathrm{Cu})$ and Manganese (Mn) in the staple food crops like pearl millet leads to ubiquitous food-related health problems. In context to this present investigation was undertaken to study the phenotypic diversity among 48 maintainer (B) and restorer lines (R) of pearl millet genotypes for grain micronutrients concentration, yield and agro-morphological traits using multivariate approach. Higher range, large value of Shannon-weaver Diversity Index for both traits and genotypes and large differences in mean values for most of the characters showed that sufficient diversity existed among the genotypes and traits. Cluster analysis using unweighted pair group method of arithmetic averages (UPGMA) grouped the genotypes into five clusters with varied number which suggested the clear differentiation among B and R lines with some exceptions. Clustering of pearl millet genotypes from different geographical locations or source/origin into same cluster has confirmed that they are genetically related, and possibly from the same progenitor, but could have been separated by geographical or ecological barrier. The principal component analysis (PCA) revealed that most of the variation $(68.83 \%)$ was accounted by first four PCA and genotypes from maintainer were clustered into left side of the biplot graph while the lines from the restorer category were distributed throughout the PCA biplot graph. Average Diversity Index of 1.883 and 3.792 for genotypes and traits respectively, further validated that the genotypes were more diverse among themselves and for all the traits studied. Association studies revealed significant positive correlation of grain $\mathrm{Fe}$ content with the grain $\mathrm{Zn}$ and $\mathrm{Cu}$ content; grain yield per plant with the plant height, panicle weight and dry fodder yield per plant; panicle weight with plant height, panicle length and dry fodder yield; panicle length with plant height and dry fodder yield per plant and dry fodder yield per plant with plant height. It indicated the likely effectiveness of simultaneous improvement of all these characters along with grain micronutrients in pearl millet. Grain yield per plant showed non-significant positive or negative correlation with grain micronutrients concentration thus suggesting improvement in nutrient content without compromising yield. The significant negative association between the grain yield and panicle weight with days to flowering has the great advantages in pearl millet cultivation as crop can fit into multiple cropping system in arid and semi-arid environments.
\end{abstract}




\section{Introduction}

Pearl millet [Pennisetum glaucum (L.) R. Br.] is a prominent tropical $\mathrm{C} 4$ small-grained cereal crop having a very high photosynthetic effectiveness and dry matter production capability. It is typically grown under the most unfavourable agro-climatic conditions where other cereals like sorghum and maize fail to produce economic yields. Moreover, pearl millet has a notable capacity to act in response to favourable environments because of its short duration and capacity for fast growth rate, thus making it an outstanding crop for short growing seasons under improved crop management (Yadav and Rai, 2013). Pearl millet is highly resilient to diverse climate conditions and is cultivated in marginal environments of arid and semi-arid tropics of Sub-Saharan Africa and Asia (Radhika Ramya et al., 2018). In India, pearl millet is the third most widely cultivated food crop after rice and wheat. It is grown on 9 million ha with an average productivity of $1,000 \mathrm{~kg}$ per hectare. It shows a higher degree of tolerance to severe drought, heat stress and high temperature (Anuradha et al., 2018 and Govindaraj et al., 2018). Pearl millet grains are the rich source of the several macro and micro-nutrients (like iron, zinc, phosphorus, and magnesium), high fiber content, $\alpha$ amylose, metabolizable energy, proteins, essential amino acids, thus ensuring food and nutritional security (Kumar et al., 2018). Pearl millet is primarily grown for food and dry fodder. Dry fodder of pearl millet is a major component of livestock ration during the dry period of year. It is also an excellent forage crop because of its lower hydrocyanic acid content than sorghum. Its green fodder is rich in protein, calcium, phosphorous and other minerals with oxalic acid within safe limits.

Development of high-yielding hybrids is an important breeding objective for pearl millet worldwide. The availability, assessment, and exploitation of genetic diversity and distance among genotypes help to develop heterotic groups which aid in selection of parents for further crossing. Moreover, assessing the extent of diversity for the economically important traits and identification of promising germplasm in untapped genetic resources of pearl millet is essential to generate knowledge useful for germplasm conservation and breeding programs. In addition to it, evaluation, characterization and classification of genotypes based on estimates of genetic divergence will help to identify diverse parental lines which can be used in hybridization program to develop potential hybrids or varieties.

Worldwide serious and widespread human health problems have been recognized due to dietary deficiency of mineral micronutrients such as iron and zinc (WHO, 2002 and Welch \& Graham, 2004). Micronutrient malnutrition increases mortality \& morbidity rates, healthcare costs and reduces labour productivity, thus affect the development of any nation (Darnton-Hill et al., 2005 and Stein, 2010). Pearl millet is grown as major staple food crop in developing and under-developed countries of Africa and Asia, so these regions are largely affected by malnutrition. Genetic resources of pearl millet are relatively untapped and need further attempts to improve the grain micronutrients such as iron, zinc, copper and manganese content.

Biofortification of staple crops through genetic means is a sustainable and most cost effective approach to tackle malnutrition problem. It has always been promising to improve the mineral nutritional status and health of poor population in both rural and urban areas of developing world (Kumar et al., 2016). Fe (iron), Zn (zinc), $\mathrm{Cu}$ (copper) and $\mathrm{Mn}$ (manganese) are known to play an important role in many crucial biological processes and are necessary for survival of 
human beings. For instance, $\mathrm{Fe}$ is an important component of haemoglobin and myoglobin; $\mathrm{Zn}$ stimulates the activities of many enzymes in the human body and is closely related to intelligence development in children and adult reproductive function; $\mathrm{Cu}$ plays key a role in the formation of red blood cells, energy production and maintaining nerve cells and the immune system and $\mathrm{Mn}$ is vital for the human body and helps in the metabolism of amino acids, cholesterol, glucose and carbohydrates (Ansari et al., 2004).

Deciphering the genetic diversity of grain micronutrients, yield and agro-morphological traits will be useful to identify contrasting parents, to maximize heterozygosity and achieve yield stability along with nutrient value in variable and changing climates (Haussmann et al., 2007 and Hausmann et al., 2012). The pattern of genetic relationships between and within accessions can be studied by multivariate analysis methods. Principal component analysis (PCA) and clustering are the two useful multivariate statistical tools for studying the relationship among the related genotypes. Cluster analysis is used to study the association between landraces while relationships between traits are statistically analyzed using PCA. These techniques have been previously applied for genetic diversity study in many crops such as finger millet (Lule et al., 2012), rice (Gana et al., 2013), and pearl millet (Pucher et al., 2015 and Kumari et al., 2016). Therefore, the present study was aimed to characterise and evaluate 48 pearl millet genotypes for grain micronutrients, yield and agro-morphological traits by clustering and PCA approach.

\section{Materials and Methods}

\section{Experimental materials and location}

Forty eight pearl millet genotypes (24 maintainer and 24 restorer lines) were sown during kharif, 2016 at Centre of Crop Improvement (CCI), S. D. Agricultural University, S.K.Nagar, Gujarat. The parental lines were of diverse origin which represented the A (PMRS, JAU, Jamnagar, Gujarat India) and $\mathrm{B}$ zone (ICRISAT, Patancheru, Hyderabad, Telangana India) of the three agro-ecological zones (A, $\mathrm{A}_{1}$ and $\mathrm{B}$ ) of pearl millet in India (table 1). Experiment was conducted at Centre for Crop Improvement (CCI), Sardarkrushinagar Dantiwada Agricultural University, Sardarkrushinagar (SDAU), Gujarat. SK. Nagar is situated at $24^{\circ} 1926^{\prime \prime}$ North latitude and $72^{\circ} 183^{\prime}$ " East longitude with an altitude of 172.00 meters above the mean sea level (Arabian Sea). The soil of experimental sight was loamy sand in texture with a $\mathrm{pH}$ of 7.5 and climatic condition falls under the category of semiarid, characterized by less than $400 \mathrm{~mm}$ of annual average rainfall.

\section{Field experiments and observations recorded}

The genotypes were planted in randomized complete block design (RCBD) with 2 replications. Each genotype was represented by 2 rows of $3 \mathrm{~m}$ length with distance of 45 $\mathrm{cm}$ between rows and $15 \mathrm{~cm}$ between plants in a row. Thinning was performed after 15 days of germination to ensure single plant per hill. From sowing till harvesting, all the recommended agronomic package of practices was followed to raise the good crops. Five plants were randomly selected and tagged for taking observations. The observations were recorded for quantitative morphological traits such as days to $50 \%$ flower, plant height $(\mathrm{cm})$, panicle length $(\mathrm{cm})$, panicle girth $(\mathrm{cm})$, panicle weight $(\mathrm{g})$ and dry fodder yield per plant $(\mathrm{g})$. During harvest main panicles of five random plants from each entry were harvested and stored separately in a cloth bag for grain micronutrients ( $\mathrm{Fe}, \mathrm{Zn}, \mathrm{Cu}$ and $\mathrm{Mn}$ content) analysis. 


\section{Grain micronutrients analysis}

The cleaned grains from each entry were oven dried at $60^{\circ} \mathrm{C}$ for 48 hours and grinded to fine powder using mortal and pestle. Grinded samples were properly labeled and stored in butter paper cover for further analysis. The grain micronutrients were estimated from the acid extract prepared by wet digestion procedure of Singh et al., (2005) using diacid mixture at Centre for Bio Science Research Laboratory, S. D. Agricultural University, S. K. Nagar, Gujarat. One gram of grinded sample was pre-digested by adding $10 \mathrm{ml}$ concentrated nitric acid $\left(\mathrm{HNO}_{3}\right)$ and kept for overnight. Further, prepared diacid mixture $\left(\mathrm{HNO}_{3}\right.$ and $\left.\mathrm{HClO}_{4}\right)$ of approximately $10 \mathrm{ml}$ was added to predigested sample. Then the samples were kept on hot plate at $200^{\circ} \mathrm{C}$ temperatures until the fume that comes out becomes colourless. After that heating was stopped,the digested sample was cooled down for 20 minutes andabout $50-60 \mathrm{ml}$ double distilled water was added. The volume of digest was filtered with Whatman filter paper and final volume of $100 \mathrm{ml}$ was made by adding double distilled water in conical flask. Care was taken at each step to avoid any contamination of samples with foreign dust particles. The samples were analyzed for iron and zinc content in Atomic Absorption Spectrophotometer (AAS), ELICO SL 194.

\section{Statistical analysis}

\section{Descriptive statistics}

The major descriptive statistics such as mean, range and coefficient of variation for each traits were computed using excel sheet program.

\section{Cluster analysis}

Hierarchical cluster analysis for grain micronutrients, yield and agro-morphological characters was performed to produce dendrogram based on the average distance between genotypes. The intergenotypic divergence was calculated using the unweighted pair group method of arithmetic averages (UPGMA). Data of cluster analysis were analyzed using PAST software, version 3.25 (Hammer, 2019).

\section{Principal components analysis}

Principal components analysis (PCA) is the data reduction technique applicable to quantitative type of data. PCA transforms multi-correlated variables into another set of uncorrelated variables for further study. These new set of variables are linear combinations of original variables.

It is based on the development of eigen-values and mutually independent eigen-vectors (principal components) ranked in descending order of variance size. Such components give scatter plots of observations with optimal properties to study the underlying variability and correlation. Suppose $\mathrm{x}_{1}, \mathrm{x}_{2}, \ldots \ldots, \mathrm{x}_{\mathrm{n}}$ be the original data in a study, then principal components may be defined as:

$\alpha^{c} 1 x=\alpha 11 x 1+\alpha 12 x 2+\cdots+\alpha 1 p x p=\sum_{j=1}^{p} \alpha 1 j x j$

Where, $\boldsymbol{\alpha}_{1} \mathrm{x}$ is the a linear function of the elements of $\mathrm{x}$ having maximum variance, and $\alpha 1$ is a vector of $p$ constants $\alpha 11, \alpha 12, \ldots, \alpha 1 \mathrm{p}$, and ' denotes transpose, so that Next, look for a linear function $\boldsymbol{\alpha}_{2} \mathrm{X}$, uncorrelated with $\boldsymbol{\alpha}_{1} \mathrm{X}$ having maximum variance, and so on, so that at the $\mathrm{k}^{\text {th }}$ stage a linear function $\boldsymbol{\alpha}_{\mathrm{k}} \mathrm{X}$ is found that has maximum variance subject to being uncorrelated with $\boldsymbol{\alpha}_{1 \mathrm{X}}, \boldsymbol{\alpha}_{2 \mathrm{X}}$.., $\boldsymbol{\alpha}_{\mathrm{k}-1 \mathrm{X}}$. The $\mathrm{k}^{\text {th }}$ derived variable, $\boldsymbol{\alpha}_{\mathrm{k}} \mathrm{X}$ is the $\mathrm{k}^{\text {th }}$ PC (Jolliffe, 2002). The biplot based on two principal components were also generated to depict the two-dimensional view of accession scores. 
Data of principal component analysis were analyzed using PAST software, version 3.25. (Hammer, 2019).

\section{Shannon-weaver Diversity Index}

Shannon diversity indices (H') were calculated to study diversity among all genotypes studied as well as among genotypes from each category (B/R lines) with the formula given by Shannon (1948):

$$
{ }_{i=1}^{N} H^{*}=-\sum p i \cdot \ln p i
$$

where $p_{i}$ is the proportion of accessions in the $i^{\text {th }}$ class of an n-class character and $n$ is the number of phenotypic classes for a character and for quantitative traits ' $n$ ' equalled 8 , based on Sturge's rule, $\mathrm{n}$, the number of frequency classes $=1+\log _{2}(N)$, where, $\mathrm{n}=$ the observed number of accessions.

The indices are standardised by dividing each value of $\mathrm{H}^{\prime}$ by $\log \mathrm{e}_{\mathrm{n}}$ to keep the value in a range of 0 to 1 in order to estimate the importance of phenotypic diversity. The data were analysed to calculate the diversity index using R statistical software, version 3.4.1 (R Development Core Team, 2017).

\section{Association analysis}

Pearson $r$ correlation was used to measure the degree of relationship between linearly related variables. The following formula was used to calculate the Pearson $r$ correlation:

$$
\mathrm{r}_{\mathrm{xy}}=\frac{n \sum x i y i-\sum x i \sum y i}{\sqrt{n} \sum x i 2-\left(\sum x i\right) 2 \sqrt{n} \sum y i 2-\left(\sum y i\right) 2}
$$

where, $r_{x y}=$ Pearson $r$ correlation coefficient between $\mathrm{x}$ and $\mathrm{y}$ variables; $\mathrm{n}=$ number of observation; $x_{i}=$ value of $x$ for the $i^{\text {th }}$ observation and $y_{i}=$ value of $y$ for $i^{\text {th }}$ observation. The data were analysed for the Pearson correlation analysis using $\mathrm{R}$ statistical software, version 3.4.1 (R Development Core Team, 2017).

\section{Results and Discussion}

\section{Genetic diversity analysis}

The major descriptive statistics such as mean, range and coefficients of variation revealed wider ranges of variations among genotypes for most of the traits studied. The range of variation was maximum for grain $\mathrm{Fe}$ content (14.00-122.00 ppm) followed by grain $\mathrm{Zn}$ content $(11.50-56.00 \mathrm{ppm})$, plant height $(61.67-153.80 \mathrm{~cm})$, panicle length (13.00$28.84 \mathrm{~cm})$, panicle weight $(0.02-0.44 \mathrm{~kg})$, grain yield per plant $(0.01-0.22 \mathrm{~kg})$ and dry fodder yield per plant $(0.33-2.93 \mathrm{~kg})$ while it was minimum for grain $\mathrm{Cu}$ content (4.5-10.5 ppm) and grain Mn content (4.5-17.5 ppm) (Table 2). Higher range, more diversity Index and large differences in mean values for most of the characters revealed that sufficient diversity existed among the genotypes and traits. The present findings were similar with previous reports in pearl millet (Dapke et al., 2014; Anuradha et al., 2018; Sharma et al., 2018 and Mahendrakar et al., 2019).

\section{Cluster analysis}

Grouping of genotypes into few numbers of homogenous clusters facilitates the selection of diverse lines for the crossing purpose. It permits precise comparison among all the possible pair of individuals and provides an opportunity for bringing together gene combinations and yielding desirable segregants from crossing between these lines. The cluster analysis through the UPGMA method grouped the genotypes into five clusters with varied number of genotypes (Fig.1). In the present study cluster analysis on the basis of mean values for grain micronutrients, yield and agro-morphological traits were studied. It was clearly observed 
that cluster I possessed genotypes with high grain iron and zinc content, dry fodder yield and panicle length. Similarly, cluster II comprised only B lines with high grain iron and zinc content, panicle girth and late flowering type. These results were in agreement with the previous findings by Sangwan et al., (2019) in pearl millet. Cluster III comprised most of the genotypes from B lines with higher panicle girth and $\mathrm{Mn}$ content. Similarly, grouping in cluster IV with genotypes both from B and R lines with early flowering habit and high panicle girth showed the findings in close agreement with previous reports of Kumari et al., (2016) and Sangwan et al., (2019). The genotypes which possessed more plant height, longer panicle length, panicle girth, panicle weight, grain yield, dry fodder yield and Mn content were grouped in cluster V (Fig.1). These results of cluster analysis for various grain micronutrients, yield and agro-morphological characters suggested clear differentiation of $\mathrm{B}$ and $\mathrm{R}$ lines with some exceptions. The initial assessment of genetic materials to enable identification of potent parents for hybridization programme based on morphological data is easy, simple and can be considered as a universal approach for evaluating genetic diversity among genotypes. Similarly, grouping of genetic materials based on quantitative data in pearl millet was reported by Shanmuganathan et al., (2006), Vidhyadhar and Devi (2007), Govindaraj et al., (2011), Drabo et al., (2013), Sathya et al., (2013), Upadhyaya et al., (2013), Sankar et al., (2014), Chaudhary et al., (2015), Kumar et al., (2015), Kumari et al., (2016) and Sangwan et al., (2019). Genotypes from different source/origin falls under the same cluster, so grouping did not happened on the basis of origin or geographical location. These results are in agreement with the findings of Burson et al., (2015) and Animasaun et al., (2017) who observed that accessions of pearl millet did not necessarily assemble into the same cluster based on their geographical origins. Clustering of pearl millet accessions together regardless of their source supports the possibility of a common progenitor but separation by geographical or ecological isolation mechanisms (Jauhar, 1981). Therefore, for any hybridization programs in pearl millet, the choice of suitable diverse parents based on genetic divergence analysis would be more rewarding than the choice based on the geographical distances.

\section{Principle component analysis}

The PCA based on correlation was used to study interrelationships among the different traits and genotypes. The first four principal components having eigen value greater than one were extracted from the mean of 11 traits and they explained $68.83 \%$ variance in pearl millet genotypes. The first principal component (PC1) was the most important and accounted $31.33 \%$ of variation. The major contributors for variation observed in first principle component were plant height, panicle length, panicle weight, grain yield per plant, dry fodder yield per plant, grain $\mathrm{Mn}$ content. A variance of 15.40, 12.78 and 9.32 were extracted from second, third and fourth principal components, respectively. The variation in PC2 were mainly due to panicle weight, grain yield per plant, grain $\mathrm{Fe}, \mathrm{Zn}$ and $\mathrm{Cu}$ content. PC3 imparted $12.78 \%$ variance mainly through days to $50 \%$ flower, plant height, panicle length, grain $\mathrm{Fe}$ and grain $\mathrm{Cu}$ content. Likewise major contributor to the variation observed in PC4 was panicle girth (Table 3). The results indicated the role of traits (specific to each PC) which contributed more towards genetic divergence in discriminating the genotypes of pearl millet. The present study was in agreement with the PCA traits analysis of Kumari et al., (2016), Animasaun et al., (2017), Radhika Ramya et al., (2017), Sangwan et al., (2019) in pearl millet. The Genotype-trait biplot based on two 
principal components were also generated to represent the two-dimensional view of eleven traits and different genotypes of pearl millet (Fig. 2). Two dimensional PCA biplot of 48 pearl millet genotypes showed that most of the lines from maintainer category were clustered in left side of the biplot graph. The lines from the restorer category were mainly present on the right side of the PCA biplot graph (Fig. 3). The two dimensional view of genotype-trait biplot based on 2 PCs in pearl millet revealed that genotypes from $B$ lines were clustered in the left side of the biplot graph and the lines from the restorer category or $\mathrm{R}$ lines were distributed throughout the PCA biplot graph (Radhika Ramya et al., 2017 and Sangwan et al., 2019).

\section{Estimation of Shannon-weaver Diversity Index}

Shannon-weaver Diversity Index was estimated which revealed sufficient diversity for both genotypes and traits. The pearl millet genotypes were diverse for all the quantitative traits and also diverse among themselves $\left(\mathrm{H}^{\prime}>0.5\right)$. Diversity index ranged from 1.712 to 2.002 for the genotypes (Table 2). Average Diversity Index of 1.883 and 3.792 for genotypes and traits respectively revealed that pearl millet genotypes were more diverse among themselves and for all the quantitative traits. The highest (2.002) and lowest (1.712) diversity indices were reported in genotypes 225SU14B and ICMB 92777, respectively from the maintainer category. Ten genotypes from $B$ lines and fifteen genotypes from $R$ lines exhibited above average diversity indices.

Genotypes, 225SU14B (2.002), 226SU14B (1.998), 106SB13 (1.976), 123SM14 (1.957), 95SM13 (1.951) and ICMB 08444 (1.950) exhibited greater diversity (Table 2). While genotypes, ICMB 92777 (1.712), 211SU14B (1.772), 131SM14 (1.790), 212SU14B
(1.811), 237SM13 (1.815) and 218SU14B (1.819) showed less diversity for all the traits studied (Table 2). However, the Shannonweaver Diversity Index for all the traits together revealed that days to $50 \%$ flower (3.869) has contributed most for the diversity among the genotypes followed by panicle girth (3.862), grain $\mathrm{Cu}$ content (3.858), panicle length (3.855), plant height (3.850), grain $\mathrm{Mn}$ content (3.835) and grain $\mathrm{Zn}$ content (3.801) (Table 2). The similar indices for trait specific Shannon-weaver Diversity Index was calculated by Kumari et al., (2016) in pearl millet germplasm accessions for determining morphological diversity.

\section{Association studies}

Correlation study of micronutrients concentration revealed that grain Fe content showed significant positive correlation with the grain $\mathrm{Zn}(0.33)$ and $\mathrm{Cu}$ content $(0.40)$ but significant negative correlation with plant height (-0.31), dry fodder yield per plant ($0.30)$ and grain Mn content (-0.45). Grain Zn content was significantly negatively correlated with plant height (-0.30) and panicle length (-0.41). Significant positive correlation were observed for the grain yield per plant with the plant height (0.39), panicle weight (0.95), dry fodder yield per plant (0.57) and significantly negative correlation with days to $50 \%$ flower (-0.41). Interestingly, in the present study grain yield per plant does not show any significant positive or negative correlation with grain micronutrients concentration. Similarly, panicle weight showed significant positive correlation with plant height (0.45), panicle length (0.32), dry fodder yield (0.60) and negative correlation with days to $50 \%$ flower (-0.43). Panicle length was positively correlated with plant height $(0.46)$ and dry fodder yield per plant (0.30) and dry fodder yield per plant exhibited significant positive correlation with plant height (0.64) (Fig. 4). 
Table.1 List of genotypes, pedigree, Source / Origin and their category

\begin{tabular}{|c|c|c|c|c|}
\hline $\begin{array}{l}\text { Sr. } \\
\text { No. }\end{array}$ & Genotype Name & Pedigree & Source / Origin & B/R line \\
\hline 1 & ICMB 99222 & (BSECBPT/91-40 x SPF3/S91-94)-3-1-1-2 & ICRISAT, Patancheru & B line \\
\hline 2 & ICMB 05888 & (SRC II C3 S1-1-1-2 x HHVBC)-5-1-1-2 & ICRISAT, Patancheru & B line \\
\hline 3 & ICMB 92777 & [843 B x (ICMPES-500-4-4-3 x ICMPES-800-3-1-2(3-4)]-7-1-3 & ICRISAT, Patancheru & B line \\
\hline 4 & ICMB 06777 & (ICMB 96333 x HHVBC-2-D2-HS-259-2)-4-B & ICRISAT, Patancheru & B line \\
\hline 5 & ICMB 95222 & $\{[843 B \times(G N S \times$ SS-48-40-4)-29-7-4-B] x (843B x ICMPES-29)-23-2-3\}-16 & ICRISAT, Patancheru & B line \\
\hline 6 & 213-SU-14B & [ICMB 96111 x 4017-2-1-B)-7-2-3 x (SRC II C3 S1-19-3-2 x HHVBC)-17-3\}-1-3-19-2-2-2-B-2-4 & PMRS, JAU, Jamnagar & B line \\
\hline 7 & 230-SU-14B & $\begin{array}{l}\text { \{[78-7088/3/SER3 AD//B282/(3/4)EB x PBLN/S95-359]-7-4-B-B-2-B-B x HHVDBC HS-10-1-2-1-1- } \\
\text { 1-4-1-1\}-10-3-3-B }\end{array}$ & PMRS, JAU, Jamnagar & B line \\
\hline 8 & ICMB 05333 & (MC 94 S1-30-2-B x HHVBC)-16-3-1-1 & ICRISAT, Patancheru & B line \\
\hline 9 & ICMB 89111 & [843B x (CNS x SS-48-40-4)-1-9-8] & ICRISAT, Patancheru & B line \\
\hline 10 & ICMB 96222 & 126B x (81B x SLR 50-1)-1-1-2 x 852B)-69-1-1 & ICRISAT, Patancheru & B line \\
\hline 11 & 225-SU-14B & $\begin{array}{l}\text { \{(MC } 94 \text { S1-34-1-B x HHVBC)-16-2-1-1-1-1-B-B-5 x (MC } 94 \text { S1-34-1-B x HHVBC)-10-4-1-2-1-B-B- } \\
\text { 1-30-2-4-3-6-4-3 }\end{array}$ & PMRS, JAU, Jamnagar & B line \\
\hline 12 & ICMB 04999 & (EBC-Gen-S1-40-2-2-1 x B-line bulk)-25-B-B & ICRISAT, Patancheru & B line \\
\hline 13 & 218-SU-14B & [(SRC II C3 S1-1-1-2 x HHVBC)-2-2-1-1-1-B-B x (81B x 4017-5-4-B)-12-3-1-3]-6-2-3-3-2 & PMRS, JAU, Jamnagar & B line \\
\hline 14 & 227-SU-14B & [(MC 94 S1-34-1-B x HHVBC)-16-1-3-1-2-2-B-B-2-B-B x ICMB 99222]-13-2-1-2 & PMRS, JAU, Jamnagar & B line \\
\hline 15 & 212-SU-14B & (ICMB 04777 x ICMB 04111)-2-2-2-2-1 & PMRS, JAU, Jamnagar & B line \\
\hline 16 & 211-SU-14B & [ICMB 96111 x 4017-2-1-B)-7-2-3 x ((SRC II C3 S1-19-3-2 x HHVBC)-17-3]-1-3-19-2-2-2-B-2-2 & PMRS, JAU, Jamnagar & B line \\
\hline 17 & 215-SU-14B & $\begin{array}{l}\{[(843 B \times \text { ICTP 8202-161-5)-20-3-B-B-3 x B-bulk]-2-B-1-2-2-B-B-B-11-1 x B-bulk (3981-4011/S06 } \\
\text { G1)\}-3-2-4- }\end{array}$ & PMRS, JAU, Jamnagar & B line \\
\hline 18 & ICMB 05222 & (ICMR-312S1-8-3-3-B x HHVBC)-9-4-1-1 & ICRISAT, Patancheru & B line \\
\hline 19 & 224-SU-14B & [EEDBC S1-425-2-1-2-3-B-1-B-7-1 x B-bulk (3981-4011/S06 G1)]-2-2-1-B & PMRS, JAU, Jamnagar & B line \\
\hline 20 & ICMB 08444 & HHVBC II D2 HS-410-1-2-4-1-3-B-2-2-3-2 & ICRISAT, Patancheru & B line \\
\hline 21 & 226-SU-14B & (ICMB 99555 x ICMB 00555)-11-1-3-B-2-B-2 & PMRS, JAU, Jamnagar & B line \\
\hline 22 & ICMB 98222 & ARD-288-1-10-1-2(RM)-5 & ICRISAT, Patancheru & B line \\
\hline 23 & ICMB 841 & DM.RESI.SELE.FROM SEED LOT NO.8015 OF 5141B & ICRISAT, Patancheru & B line \\
\hline 24 & 261-SU-14B & 09888B x [(HHVDBC HS-246-1-2-1-2 x ICMB 01222)-4-2-1-1]-2-1 & PMRS, JAU, Jamnagar & B line \\
\hline
\end{tabular}




\begin{tabular}{|c|c|c|c|c|}
\hline Sr. No. & Genotype Name & Pedigree & Source / Origin & $\mathrm{B} / \mathrm{R}$ line \\
\hline 25 & 121-SM-13 & (MC 94 C2-S1-3-2-2-2-1-3-B-B x ICMR 312 S1-3-2-3-2-1-1-B-B)-B-17-4-3-2 & PMRS, JAU, Jamnagar & $\mathrm{R}$ line \\
\hline 26 & $\mathrm{~J}-2510$ & JBV 3-S1-231 & PMRS, JAU, Jamnagar & R line \\
\hline 27 & $\mathrm{~J}-2500$ & AIB-1-2-B & PMRS, JAU, Jamnagar & $\mathrm{R}$ line \\
\hline 28 & $\mathrm{~J}-2480$ & AS-14 (B-Senegal-2-5 x 700651)-2-1-4 (IPC-655) & PMRS, JAU, Jamnagar & $\mathrm{R}$ line \\
\hline 29 & $123-\mathrm{SB}-14$ & $(\mathrm{~J}-2340 \times \mathrm{J}-2454)-15-10-8-3-1-1-1$ & PMRS, JAU, Jamnagar & R line \\
\hline 30 & 106-SB-13 & (MC 94 C2-S1-3-2-2-2-1-3-B-B x ICMR 312 S1-3-2-3-2-1-1-B-B)-B-34-4-1 & PMRS, JAU, Jamnagar & $\mathrm{R}$ line \\
\hline 31 & 131-SM-14 & (MRC HS-86-1-1-5-B-B-B-B-B x MRC S1-54-2-3-B-B-1-B-B)-19 & PMRS, JAU, Jamnagar & R line \\
\hline 32 & $\mathrm{~J}-2523$ & MRC HS 130-2-2-1-B-B-1-B-B & PMRS, JAU, Jamnagar & $\mathrm{R}$ line \\
\hline 33 & 113-SB-13 & (MC 94 C2-S1-3-2-2-2-1-3-B-B x ICMR 312 S1-3-2-3-2-1-1-B-B)-B-34-4-1 & PMRS, JAU, Jamnagar & $\mathrm{R}$ line \\
\hline 34 & 124-SB-14 & $(\mathrm{J}-2405 \times \mathrm{J}-2480)-13-10-2-1-1-1-1$ & PMRS, JAU, Jamnagar & $\mathrm{R}$ line \\
\hline 35 & $\mathrm{~J}-2549$ & $($ IPC $107 \times$ SDMV 90031-S1-84-1-1-1-1)-1-2-1-3-B & PMRS, JAU, Jamnagar & $\mathrm{R}$ line \\
\hline 36 & 237-SM-13 & ICTP 8203 & PMRS, JAU, Jamnagar & $\mathrm{R}$ line \\
\hline 37 & 94-SB-13 & (EERC-HS-8)-20-1-5 & PMRS, JAU, Jamnagar & $\mathrm{R}$ line \\
\hline 38 & 128-SM-14 & (EERC-HS-32)-B-8-1-1-B & PMRS, JAU, Jamnagar & $\mathrm{R}$ line \\
\hline 39 & 199-SM-13 & (MC 94 C2-S1-3-2-2-2-1-3-B-B x ICMR 312 S1-3-2-3-2-1-1-B-B)-B-22-2-1 & PMRS, JAU, Jamnagar & $\mathrm{R}$ line \\
\hline 40 & 109-SB-13 & (MC 94 C2-S1-3-2-2-2-1-3-B-B x ICMR 312 S1-3-2-3-2-1-1-B-B)-B-34-4-1 & PMRS, JAU, Jamnagar & $\mathrm{R}$ line \\
\hline 41 & 123-SM-14 & $(\mathrm{J}-2340 \times \mathrm{J}-2454)-15-10-8-3-1-1-1$ & PMRS, JAU, Jamnagar & $\mathrm{R}$ line \\
\hline 42 & 99-SM-13 & $\begin{array}{l}\text { (SRC II C3 S1-19-3-2 x HHVBC)-3-5-1P2 x ((ICMV IS } 94206 \text { S1-15-2) x }\{(\text { SRC II C3 S1-19-3-2 x } \\
\text { HHVBC)-5-3-1\})-B-1-2-1-1)-B-2-2-2-1 }\end{array}$ & PMRS, JAU, Jamnagar & $\mathrm{R}$ line \\
\hline 43 & 93-SM-13 & CGP S1-14-1 & PMRS, JAU, Jamnagar & R line \\
\hline 44 & 95-SM-13 & (ICMB 04888 x ICMB 02333)-3-1-3-1 & PMRS, JAU, Jamnagar & $\mathrm{R}$ line \\
\hline 45 & 110-SB-13 & (MC 94 C2-S1-3-2-2-2-1-3-B-B x ICMR 312 S1-3-2-3-2-1-1-B-B)-B-17-4-3-2-B-B & PMRS, JAU, Jamnagar & $\mathrm{R}$ line \\
\hline 46 & 108-SB-13 & (J 834 x 700516)-1-4-4-2-4-B-2-2-B-B-B-1 & PMRS, JAU, Jamnagar & $\mathrm{R}$ line \\
\hline 47 & 73-SB-13 & ICMR 312 S1-8-1-1-1-1-B-B-B-1-B & PMRS, JAU, Jamnagar & $\mathrm{R}$ line \\
\hline 48 & $\mathrm{~J}-2512$ & (PPMI-362 x IP-5738-1) x RIB-3135-18-5-3-8-B & PMRS, JAU, Jamnagar & $\mathrm{R}$ line \\
\hline
\end{tabular}


Table.2 Mean values, Shannon-weaver Diversity Index (H') of 48 genotypes and descriptive statistics of 11 traits in pearl millet

\begin{tabular}{|c|c|c|c|c|c|c|c|c|c|c|c|c|c|}
\hline $\begin{array}{l}\text { Sr. } \\
\text { No. }\end{array}$ & Genotype & $\begin{array}{c}\text { Days } \\
\text { to } \\
\mathbf{5 0 \%} \\
\text { Flower }\end{array}$ & $\begin{array}{c}\text { Plant } \\
\text { Height } \\
(\text { cm) }\end{array}$ & $\begin{array}{c}\text { Panicle } \\
\text { Length } \\
\text { (cm) }\end{array}$ & $\begin{array}{l}\text { Panicle } \\
\text { Girth } \\
\text { (mm) }\end{array}$ & $\begin{array}{c}\text { Panicle } \\
\text { Weight } \\
\text { (kg) }\end{array}$ & $\begin{array}{c}\text { Grain } \\
\text { Yield } \\
(\mathbf{k g})\end{array}$ & $\begin{array}{l}\text { Dry } \\
\text { Fodder } \\
\text { Yield } \\
(\mathbf{k g}) \\
\end{array}$ & $\begin{array}{c}\text { Grain } \\
\text { Fe } \\
\text { Content } \\
\text { (ppm) }\end{array}$ & $\begin{array}{c}\text { Grain } \\
\text { Zn } \\
\text { content } \\
\text { (ppm) }\end{array}$ & $\begin{array}{c}\text { Grain } \\
\text { Cu } \\
\text { content } \\
\text { (ppm) }\end{array}$ & $\begin{array}{c}\text { Grain } \\
\text { Mn } \\
\text { content } \\
\text { (ppm) }\end{array}$ & $\begin{array}{c}\text { Shannon- } \\
\text { weaver } \\
\text { Diversity Index } \\
\text { (H) }\end{array}$ \\
\hline 2 & ICMB-05888 & 60.50 & 109.49 & 28.84 & 21.38 & 0.15 & 0.05 & 1.05 & 85.50 & 32.50 & 8.00 & 11.50 & 1.833 \\
\hline 3 & ICMB-92777 & 59.50 & 129.17 & 18.84 & 22.48 & 0.10 & 0.04 & 2.93 & 17.00 & 15.50 & 6.00 & 14.00 & 1.712 \\
\hline 4 & ICMB-06777 & 63.50 & 105.67 & 16.17 & 27.85 & 0.08 & 0.05 & 0.74 & 56.50 & 27.00 & 9.50 & 11.00 & 1.852 \\
\hline 7 & 230SU-14B & 62.00 & 62.50 & 14.91 & 20.31 & 0.15 & 0.07 & 0.46 & 103.00 & 32.00 & 9.50 & 11.00 & 1.861 \\
\hline 8 & ICMB-05333 & 61.00 & 76.67 & 20.67 & 26.28 & 0.06 & 0.05 & 0.42 & 97.00 & 42.50 & 8.00 & 6.50 & 1.875 \\
\hline 9 & ICMB-89111 & 56.50 & 87.17 & 16.50 & 20.35 & 0.14 & 0.06 & 0.54 & 77.00 & 56.00 & 7.50 & 10.00 & 1.893 \\
\hline 10 & ICMB-96222 & 56.00 & 85.00 & 16.50 & 19.03 & 0.02 & 0.01 & 0.42 & 122.00 & 39.50 & 8.50 & 12.00 & 1.826 \\
\hline 11 & 225SU-14B & 55.50 & 61.67 & 16.50 & 28.62 & 0.16 & 0.07 & 0.81 & 22.50 & 21.00 & 7.00 & 14.00 & 2.002 \\
\hline 12 & ICMB-04999 & 61.00 & 92.50 & 16.50 & 22.51 & 0.08 & 0.03 & 0.37 & 107.00 & 44.00 & 9.00 & 14.00 & 1.879 \\
\hline 17 & 215SU-14B & 56.50 & 80.00 & 14.00 & 28.11 & 0.13 & 0.04 & 0.42 & 95.50 & 37.50 & 9.50 & 8.00 & 1.909 \\
\hline 18 & ICMB-05222 & 61.00 & 87.50 & 23.67 & 26.36 & 0.10 & 0.04 & 0.79 & 94.00 & 23.00 & 7.00 & 8.50 & 1.898 \\
\hline 19 & 224SU-14B & 59.50 & 120.32 & 19.50 & 24.70 & 0.09 & 0.03 & 1.34 & 69.50 & 30.00 & 8.00 & 15.50 & 1.910 \\
\hline 20 & ICMB-08444 & 53.50 & 108.00 & 22.34 & 22.23 & 0.44 & 0.21 & 1.38 & 57.00 & 25.50 & 7.00 & 16.00 & 1.950 \\
\hline 21 & 226SU-14B & 60.50 & 82.67 & 13.00 & 28.79 & 0.11 & 0.04 & 0.55 & 47.00 & 53.50 & 8.00 & 17.50 & 1.998 \\
\hline 22 & ICMB-98222 & 57.00 & 102.50 & 14.67 & 26.91 & 0.18 & 0.09 & 0.85 & 91.00 & 45.50 & 7.50 & 7.00 & 1.894 \\
\hline 23 & ICMB-841 & 57.50 & 122.17 & 24.00 & 21.01 & 0.18 & 0.07 & 0.73 & 57.00 & 15.50 & 8.00 & 7.50 & 1.850 \\
\hline 24 & 261SU-14B & 50.00 & 115.84 & 17.50 & 24.79 & 0.05 & 0.01 & 0.32 & 56.50 & 18.00 & 7.00 & 8.50 & 1.859 \\
\hline 25 & 121SM-13R & 59.00 & 108.00 & 20.00 & 27.76 & 0.14 & 0.04 & 0.84 & 55.00 & 34.50 & 6.00 & 12.50 & 1.946 \\
\hline 26 & J2510R & 53.00 & 117.67 & 19.83 & 24.22 & 0.14 & 0.08 & 0.63 & 53.50 & 21.00 & 10.50 & 10.00 & 1.908 \\
\hline 27 & J2500R & 61.50 & 140.17 & 19.50 & 25.12 & 0.10 & 0.04 & 1.17 & 96.00 & 24.00 & 8.50 & 7.00 & 1.822 \\
\hline 28 & J2480R & 61.00 & 117.00 & 16.33 & 19.88 & 0.16 & 0.07 & 0.61 & 110.00 & 23.00 & 8.50 & 9.00 & 1.827 \\
\hline
\end{tabular}




\begin{tabular}{|c|c|c|c|c|c|c|c|c|c|c|c|c|c|}
\hline 29 & $123 \mathrm{SB} 14$ & 60.50 & 122.67 & 21.34 & 19.34 & 0.08 & 0.03 & 1.10 & 24.50 & 28.00 & 6.00 & 11.50 & 1.866 \\
\hline 30 & $106 \mathrm{SB} 13$ & 55.50 & 103.50 & 24.00 & 23.13 & 0.34 & 0.15 & 1.22 & 33.50 & 24.00 & 8.50 & 13.50 & 1.976 \\
\hline 31 & 131SM14 & 58.50 & 147.80 & 19.00 & 21.23 & 0.31 & 0.16 & 2.00 & 21.00 & 21.50 & 7.50 & 9.50 & 1.790 \\
\hline 33 & $113 \mathrm{SB} 13$ & 54.50 & 124.35 & 24.50 & 25.51 & 0.41 & 0.15 & 1.49 & 54.50 & 26.50 & 7.00 & 11.50 & 1.932 \\
\hline 34 & $124 \mathrm{SB} 14$ & 60.00 & 119.17 & 17.84 & 21.59 & 0.10 & 0.05 & 0.42 & 54.50 & 23.00 & 5.50 & 13.50 & 1.891 \\
\hline 35 & $\mathrm{~J} 2549$ & 61.00 & 153.80 & 24.50 & 22.41 & 0.33 & 0.14 & 2.13 & 85.50 & 22.50 & 8.00 & 8.00 & 1.838 \\
\hline 37 & $94 \mathrm{SB} 13$ & 60.00 & 140.00 & 17.67 & 22.93 & 0.14 & 0.04 & 0.96 & 43.50 & 37.50 & 6.50 & 11.00 & 1.872 \\
\hline 38 & 128SM14 & 61.50 & 125.00 & 21.50 & 19.65 & 0.06 & 0.02 & 1.20 & 48.00 & 47.00 & 8.00 & 11.00 & 1.928 \\
\hline 39 & 199SM13 & 53.50 & 116.00 & 21.34 & 29.88 & 0.18 & 0.05 & 1.18 & 31.50 & 25.00 & 6.00 & 10.50 & 1.926 \\
\hline 40 & 109SB13 & 53.00 & 120.30 & 21.50 & 28.51 & 0.27 & 0.13 & 0.85 & 66.00 & 24.50 & 7.50 & 9.50 & 1.924 \\
\hline 41 & 123SM14 & 64.50 & 98.00 & 18.67 & 29.39 & 0.08 & 0.04 & 1.28 & 55.50 & 17.00 & 8.50 & 10.50 & 1.957 \\
\hline 45 & 110SB13 & 59.00 & 140.50 & 21.12 & 24.22 & 0.38 & 0.16 & 1.60 & 24.50 & 30.50 & 5.50 & 13.00 & 1.869 \\
\hline 46 & $108 \mathrm{SB} 13$ & 54.00 & 139.99 & 17.17 & 18.63 & 0.33 & 0.21 & 2.02 & 48.50 & 45.00 & 8.00 & 11.00 & 1.901 \\
\hline 47 & 73SB13 & 63.50 & 79.17 & 18.50 & 23.09 & 0.06 & 0.03 & 0.49 & 56.50 & 25.00 & 6.00 & 4.50 & 1.944 \\
\hline \multirow[t]{7}{*}{48} & $\mathrm{~J} 2512$ & 55.00 & 127.67 & 19.67 & 24.86 & 0.35 & 0.19 & 1.61 & 64.00 & 21.00 & 8.50 & 8.50 & 1.904 \\
\hline & Mean & 58.30 & 111.45 & 19.54 & 23.93 & 0.17 & 0.071 & 1.01 & 60.44 & 29.54 & 7.58 & 10.79 & 1.883 \\
\hline & Minimum & 50 & 61.67 & 13 & 18.55 & 0.02 & 0.01 & 0.33 & 14 & 11.5 & 4.5 & 4.5 & 1.712 \\
\hline & Maximum & 65 & 153.8 & 28.84 & 29.88 & 0.44 & 0.22 & 2.93 & 122 & 56 & 10.5 & 17.5 & 2.002 \\
\hline & CD @ 5\% & 6.84 & 31.29 & 5.53 & 6.14 & 0.15 & 0.07 & NS & 12.30 & 9.60 & NS & NS & \\
\hline & CV\% & 5.83 & 13.96 & 14.05 & 12.75 & 45.52 & 48.63 & 72.66 & 10.15 & 16.12 & 30.65 & 44.28 & \\
\hline & $\mathrm{H}^{\prime}$ & 3.869 & 3.850 & 3.855 & 3.862 & 3.657 & 3.622 & 3.732 & 3.767 & 3.801 & 3.858 & 3.835 & 3.792 \\
\hline
\end{tabular}

H'= Shannon-weaver Diversity Index; CD @ 5\%=Critical Difference @ 5\% level of significance; CV\%= Per cent Coefficient of Variation 
Table.3 Principal Components of eleven quantitative traits in pearl millet

\begin{tabular}{|l|c|c|c|c|}
\hline Principal Component & PC1 & PC2 & PC3 & PC4 \\
\hline Loadings & & & & \\
\hline Days to 50\% Flower & -0.38 & -0.37 & 0.47 & 0.06 \\
\hline Plant Height(cm) & 0.76 & -0.14 & 0.27 & -0.10 \\
\hline Panicle Length(cm) & 0.54 & -0.20 & 0.54 & 0.10 \\
\hline Panicle Girth(mm) & -0.07 & 0.05 & -0.48 & 0.82 \\
\hline Grain Weight(kg) & 0.84 & 0.43 & -0.13 & 0.00 \\
\hline Grain Yield/Plant(kg) & 0.78 & 0.51 & -0.13 & -0.06 \\
\hline Dry Fodder Yield/Plant(kg) & 0.79 & 0.00 & 0.05 & 0.03 \\
\hline Grain Fe Content(ppm) & -0.45 & 0.67 & 0.37 & 0.01 \\
\hline Grain Zn Content(ppm) & -0.42 & 0.41 & -0.30 & -0.38 \\
\hline Grain Cu Content(ppm) & -0.32 & 0.47 & 0.23 & -0.06 \\
\hline Grain Mn Content(ppm) & 0.13 & -0.46 & -0.52 & -0.43 \\
\hline Eigen Value & 3.45 & 1.69 & 1.41 & 1.02 \\
\hline \% Variance & 31.33 & 15.40 & 12.78 & 9.32 \\
\hline
\end{tabular}

Significant positive association of various traits gives an insight on simultaneous selection of characters and it means selection for these traits will lead to simultaneous improvement in grain yield and micronutrients level in crop plants.

Conclusively, trait association study of yield and agronomical traits revealed that significant positive correlation existed between grain $\mathrm{Fe}$ content with the grain $\mathrm{Zn}$ $(0.33)$ and $\mathrm{Cu}$ content $(0.40)$; grain yield per plant with the plant height $(0.39)$, panicle weight (0.95), dry fodder yield per plant (0.57); panicle weight with plant height (0.45), panicle length (0.32), dry fodder yield (0.60); panicle length with plant height $(0.46)$ and dry fodder yield per plant (0.30) and dry fodder yield per plant with plant height (0.64).

The similar association was also reported by several workers for yield and related traits in pearl millet namely, Pareek, (2002), Borkhataria et al., (2005), Izge et al., (2006), Kale et al., (2011), Atif et al., (2012), Dapke et al., (2014), Kumar et al., (2016), Singh and Singh (2016), Bhaskar et al., (2017), Talawar et al., (2017), Anuradha et al., (2018), Sharma et al., (2018). The positive correlation of grain micronutrients and yield with these characters implies that improving one or more components traits could result in higher nutrient contents and grain yield in pearl millet. For any biofortification programme, an important aspect is to take are that enhancement in nutrient value should not be at the cost of grain yield.

Therefore, a correlation study was conducted between grain yield per plant and grain $\mathrm{Fe}$, $\mathrm{Zn}, \mathrm{Cu}$ and $\mathrm{Mn}$ content. Interestingly, in the present study grain yield per plant showed non-significant positive or negative correlation with grain micronutrients concentration thus suggesting scope of improvement in nutrient value without sacrificing yield. This is supported by the studies of Gupta et al., (2009), Rai et al., (2012), Kanatti et al., (2014) and Sangwan et al., (2019). Earlier studies on pearl millet for grain micronutrients concentration by Velu $e t$ al., (2007, 2008a, 2008b), Gupta et al., (2009), Govindaraj et al., (2012, 2013), Rai et al., (2012, 2013, 2015) and Anuradha et al., (2018) also showed a highly significant and positive correlation between the $\mathrm{Fe}$ and $\mathrm{Zn}$ contents indicating that these two traits can be improved simultaneously. 


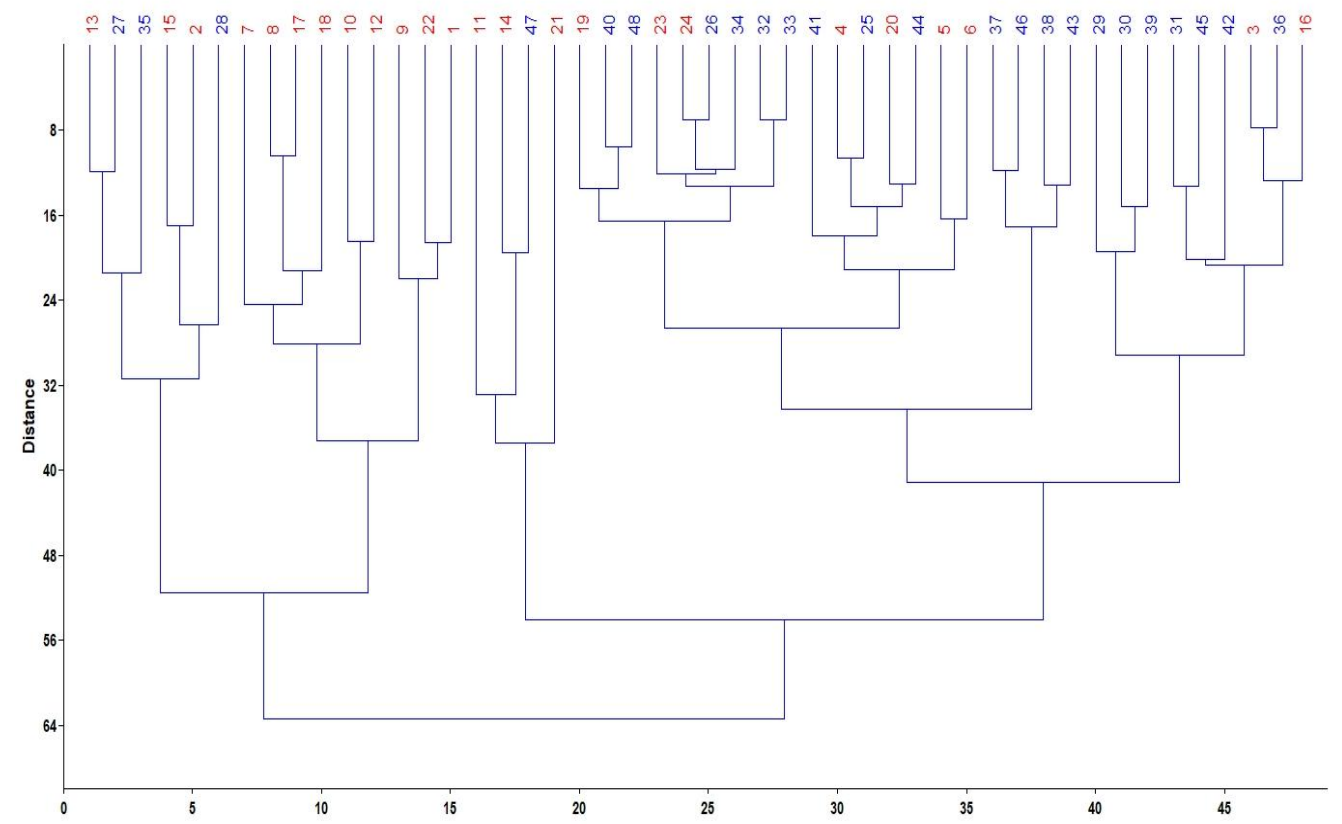

Fig.1 Dendrogram showing 24 maintainer lines (red colour) and 24 restorer lines (blue colour) of pearl millet

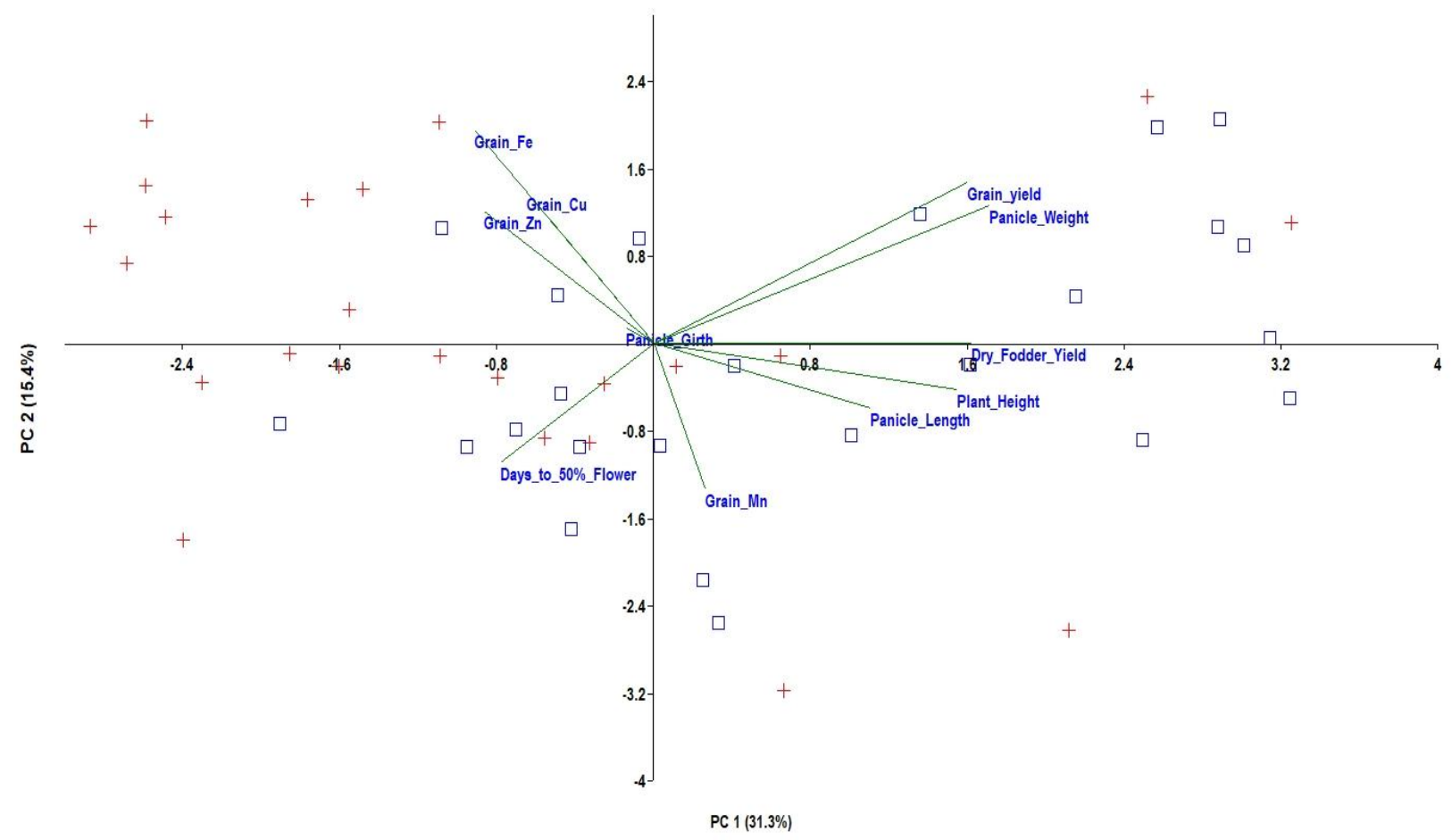

Fig.2 PCA biplot showing 11 quantitative traits along with 24 maintainer lines (red colour) and 24 restorer lines (blue colour) of pearl millet 


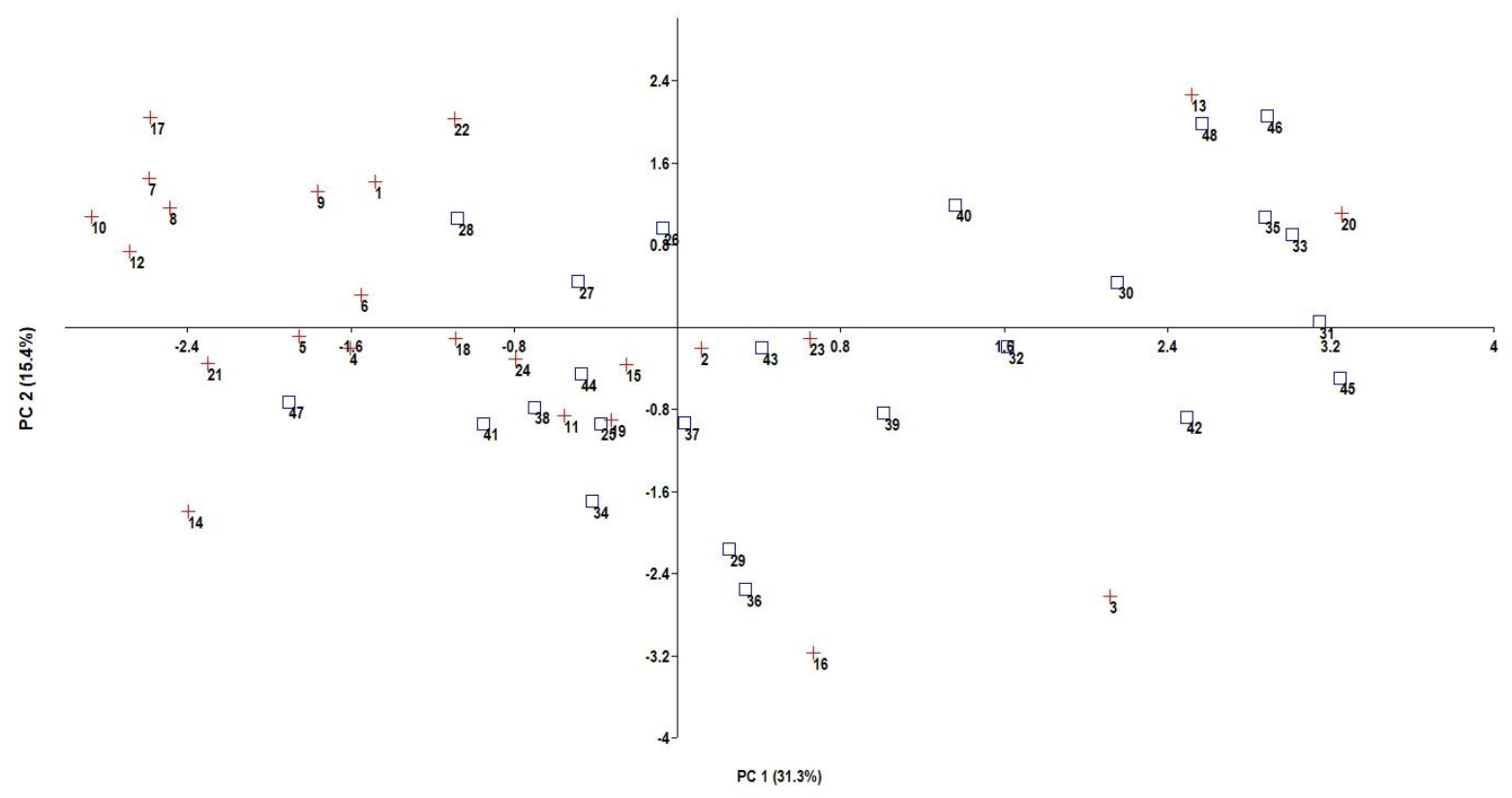

Fig.3 PCA biplot showing 24 maintainer lines (red colour) and 24 restorer lines

(blue colour) of pearl millet

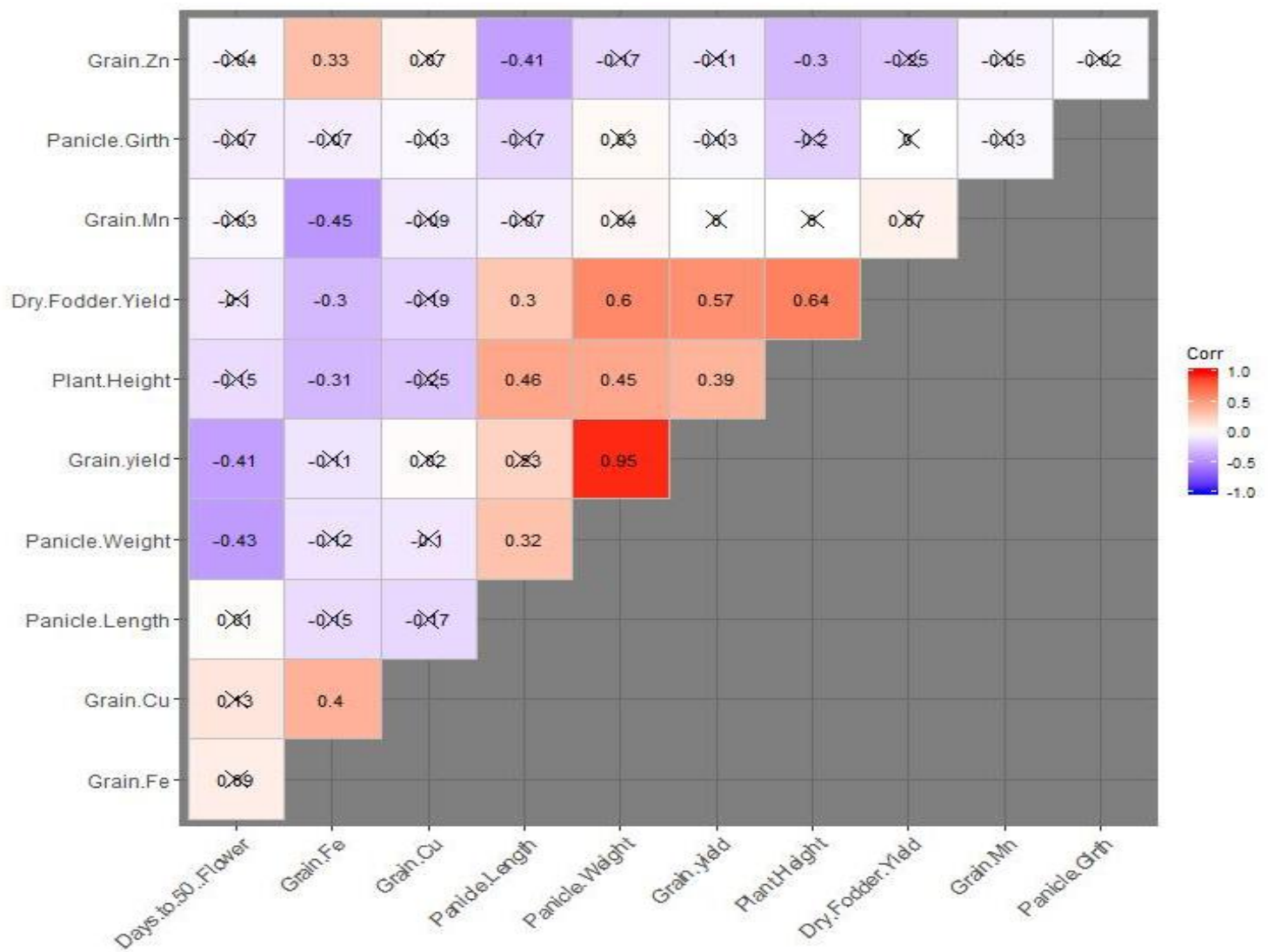

Fig.4 Pearson's correlation among 11 quantitative traits in pearl millet 
The present findings showed significant positive association between grain $\mathrm{Fe}$ and $\mathrm{Cu}$ content in contrast to earlier work of Anuradha et al., (2018) who reported nonsignificant association between them. This finding would further enable simultaneous improvement of grain $\mathrm{Fe}$ and $\mathrm{Cu}$ content in pearl millet breeding programme The grain $\mathrm{Fe}$ content showed significant negative correlation with plant height $(-0.31)$, dry fodder yield per plant (-0.30) and grain Mn content (-0.45).

Likewise, grain $\mathrm{Zn}$ content showed negative association with plant height (-0.30) and panicle length (-0.41); grain yield per plant with days to $50 \%$ flower $(-0.41)$ and panicle weight with days to $50 \%$ flower $(-0.43)$. The significant negative association between the grain yield and panicle weight with days to flowering has great advantages in pearl millet cultivation in arid and semi-arid environments. Early flowering habit is preferred trait for its cultivation as it enables the crop to mature earlier and consequently escape terminal heat and water stress in short season environments and permits multiple cropping system. Likewise, negative association between the grain yield and days to flowering in pearl millet was reported by several workers (Dapke et al., 2014 and Sangwan et al., 2019).

An accurate assessment of genetic diversity is important in crop breeding and improvement. It is established that considerable phenotypic diversity existed among the maintainer and restorer lines of pearl millet in the present study. Clustering of the genotypes independent of the geographical location or source/origin suggested that hybridizing the genetically diverse parents belonging to different clusters could provide an opportunity for bringing genes of diverse nature together for its improvement. Clustering of pearl millet genotypes from different source/origin into same cluster has confirmed that they are genetically related, and possibly from the same parent, but could have been separated by geographical or ecological isolation mechanisms. Cluster formation on the basis of grain micronutrients, yield and agro-morphological characters suggested clear differentiation of B and $\mathrm{R}$ lines with some deviations. Principal component biplot supported the result obtained by cluster analysis which further validated the diversity pattern in the pearl millet population. Further characterisation and genetic diversity analysis in pearl millet genotypes using molecular techniques should be conducted.

\section{References}

Animasaun, D.A., Morakinyo, J.A., Krishnamurthy, R. and Mustapha, O.T. 2017. Genetic divergence of nigerian and Indian pearl millet accessions based on agronomical and morphological traits. $J$. Agric Sci., 62(2):115-131.

Ansari, T.M., Ikram, N., Najam-ul-Haq, M., Fayyaz, I., Fayyaz, Q., Ghafoor, I. and Khalid, N. 2004. Essential trace metal (Zinc, Manganese, Copper and Iron) levels in plants of medicinal importance. $J$ Biol Sci., 4(2):95-99.

Anuradha, N., Satyavathi, C. T., Bharadwaj, C., Sankar, M., Singh, S. P. and Pathy, T. L. 2018. Pearl millet genetic variability for grain yield and micronutrients in the arid zone of India. J. Pharmacog. Phytochem., 7(1): 875-878.

Atif, A.L., Awadalla, A.A. and Atif, E.L. 2012. Character association and path analysis in pearl millet (Pennisetum glaucum L.). Am. J. Exp. Agric., 2(3): 370-381.

Bhasker, K., Shashibhushan, D., Murali Krishna, K., and Bhave, M.H.V. 2017. Correlation and path analysis for grain yield and it components in pearl millet [Pennisetum glaucum (L). R.Br.]. Bull. Env. Pharmacol. Life Sci. 6(1): 104-106.

Borkhataria, P.R., Bhatiya, V.J., Pandya, H.M. and Value MG. 2005. Variability and 
correlation studies in pearl millet. Nat. J. Plant Improv., 7:21-23.

Burson, L.B., Renganayaki, K., Dowling, C.D., Hinze, L.L., and Jessup, R.W. 2015. Genetic Diversity among pentaploid buffelgrass Accessions. Crop Sci., 55: 6371645.

Chaudhary, S., Sagar, P., Hooda, B.K. and Arya, R.K. 2015. Multivariate analysis of pearl millet data to delineate genetic variation. Forage Res., 40(4): 201-208.

Dapke, J.S., Shah, D.S., Pawar, G.N., Dhembre, V.M. and Kumar, M. 2014. Genetic Variability and character association over environment in pearl millet [Pennisetum glaucum (L.) R. Br.] under dryland conditions of Gujarat, The Bioscan., 9(2): 863-867.

Darnton-Hill, I., Webb, P., Harvey, P.W., Hunt, J.M., Dalmiya, N., Chopra, M., Ball, M.J., Bloem, M.W. and deBenoist, B. 2005. Micronututrient deficiencies and gender: Social and economic costs. Am. J. Clin. Nutr., 81:1198S-1205S.

Drabo, I., Zangre, R.G., Sawadogo, M. and Ouedraogo, M. 2013. Genetic variability and estimates of genetic parameters in Burkina faso's pearl millet landraces. Int. J. Agric. Forestry., 3(7): 367-373.

Gana, A.S., Shaba, S.Z. and Tsado, E.K. 2013. Principal component analysis of morphological traits in thirty-nine accessions of rice (Oryza sativa L.) grown in a rainfed lowland ecology of Nigeria. $J$. Plant Breed. Crop Sci., 5: 120-126.

Gupta, S.K., Nepolean, T., Sankar, S.M., Rathore, A., Das, R.R., Rai, K.N. and Hash, C.T. 2015. Patterns of molecular diversity in current and previously developed hybrid parents of pearl millet [Pennisetum glaucum (L.) R. Br.]. Am. J. Plant Sci., 6: 1697-1712.

Gupta, S.K., Velu, G., Rai, K.N. and Sumalini, K. 2009. Association of grain iron and zinc content with grain yield and other traits in pearl millet [Pennisetum glaucum (L.) R. Br.]. Crop Improvement., 36: 4-7.

Govindaraj, M. and Rai, K.N., Shanmugasundaram, P., Dwivedi, S.L., Sahrawat, K.L., Muthaiah, A.R., Rai, A.S. 2013. Combining ability and heterosis for grain iron and zinc densitiesin pearl millet. Crop Sci., 53: 507-517.

Govindaraj, M., Rao, A. S., Shivade, H. and Rai, K. N. 2018. Effect of grain colour on iron and zinc density in pearl millet. Indian $J$. Genet., 78(2): 247-251.

Govindaraj, M., Rai, K.N., Shanmugasundaram, P. and Rao, A.S. 2012. Efficiency of single plant selection for grain iron and zinc density in pearl millet. Eur J Plant Sci Biotechnol., 6: 114-117.

Govindaraj, M., Selvi, B. and Kumar, I.S. 2011. Genetic diversity studies in indigenous pearl millet [Pennisetum glauccum (L.) R. Br.] accessions based on biometrical and nutritional quality traits. Indian J. Plant Genet. Resour., 24(2): 186-193.

Hammer, Ø. 2019. PAlaeontological STatistics, Version 3.25, Reference Manual. Oslo: University of Oslo; 2019. https://folk.uio.no/ohammer/past/past3man ual.pdf

Haussmann, B.I.G., Boureima, S.S., Kassari, I.A., Moumouni, K.H. and Boubacar, A. 2007. Mechanisms of adaptation to climate variability in West African pearl millet landraces-a preliminary assessment. $J$. SAT Agric Res., 3: 1-3.

Haussmann, B.I.G., Fred Rattunde, H., WeltzienRattunde, E., Traore, P.S.C., vomBrocke, K. and Parzies, H.K. 2012. Breeding strategies for adaptation of pearl millet and sorghum to climate variability and change in West Africa. J Agron Crop Sci., 198:327-339.

Izge, U., Kadams, M. and Gungula, T. 2006. Studies on character association and path analysis of certain quantitative characters among parental line of pearl millet (Pennisetum glaucum) and their $\mathrm{F}_{1}$ hybrids in a diallel cross. Afr. J. Agric. Res., 1(5): 194-198.

Jauhar, P.P. 1981. Cytogenetics and breeding of pearl millet and related species. In: A.A. Sandberg, (Ed.), Progress and topics in cytogenetics. (pp. 1-145). Alan R Liss Inc., New York.

Jolliffe, I.T. 2002. Principal component analysis. Second Edition, Springer-Verlag, Berlin.

Kale, B.H., Jadeja, G.C. and Patel, K.K. 2011. Genetic variability, correlation and path 
coefficient analysis in segregating generation of pearl millet [Pennisetum glaucum (L) R. Br.]. Int. J. Agric. Sci., 7(2): 373-377.

Kanatti, A., Rai, K.N., Radhika, K., Govindaraj, M., Sahrawat, K.L. and Rao, A.S. 2014. Grain iron and zinc density in pearl millet: combining ability, heterosis and association with grain yield and grain size. SpringerPlus 3: 763, https://doi.org/10.1186/2193-1801-3-763

Kumari, J., Bag, M., Pandey, S., Jha, S.K., Chauhan, S.S., Jha, G.K., Gautam, N.K. and Dutta, M. 2016. Assessment of phenotypic diversity in pearl millet [Pennisetum glaucum (L.) R. Br.] germplasm of Indian origin and identification of trait-specific germplasm. Crop Pasture Sci., 67: 1223-1234.

Kumar, M., Gupta, P.C. and Shekhawat, H.V.S. 2016. Correlation studies among pearl millet [Pennisetum glaucum (L.) R.Br.] hybrids. Electron. J. Plant Breed., 7(3): 727-729.

Kumar, R., Verma, U., Malik, V. and Vart, D. 2015. Multivariate analysis for selection of diverse genotypes in pearl millet germplasm. Forage Res., 41(2): 73-77.

Kumar, S., Hash, C. T., Nepolean, T., Mahendrakar, M. D., Satyavathi, C. T., Singh, G., Rathore, A., Yadav, R. S., Gupta, R. and Srivastava, R. K. 2018. Mapping grain iron and zinc content quantitative trait loci in an iniadiderived immortal population of pearl millet. Genes., 9(5):

248 ,

https://doi.org/10.3390/genes9050248

Kumar, S., Hash, C.T., Thirunavukkarasu, N., Singh, G., Rajaram, V., Rathore, A., Senapathy, S., Mahendrakar, M.D., Yadav, R.S. and Srivastava, R.K. 2016. Mapping quantitative trait loci controlling high iron and zinc content in self and open pollinated grains of pearl millet [Pennisetum glaucum (L.) R. Br.]. Front. Plant Sci., 7:1636, https://doi.org/10.3389/fpls.2016.01636

Lule, D., Kassahun, T., Masresha, F. and Santie, D.V. 2012. Multivariate analysis for quantitative traits in finger millet (Eleusine coracana subsp. coracana) population collected from Eastern and Southeastern
Africa: detection for patterns of genetic diversity. Int. J. Agric. Res., 7: 303-314.

Mahendrakar, M.N., Kumar, S., Singh, R.B., Rathore, A., Potupureddi, G., Kavi Kishor, P. B., Gupta, R. and Srivastava, R.K. 2019. Genetic variability, genotype $\times$ environment interaction and correlation analysis for grain iron and zinc contents in recombinant inbred line population of pearl millet [Pennisetum glaucum (L). R. Br.]. Indian J. Genet., 79(3): 545-551.

Pareek, S. 2002. Correlation and path anaiysis in pearl millet (Pennisetum glaucum (L.) R. Br.). Res Crop., 3(1): 75-77.

Pucher, A., Angarawai, O.S.I., Gondah, J., Zangre, R.G., Ouedraogo, M., Sanogo, M.D., Boureima, S., Hash, C.T. and Haussmann, B.I.G. 2015. Diversity and agromorphological characterization of West and Central African pearl millet accessions. Crop Sci., 55: 737-748.

Radhika Ramya, A., Ahamed, M.L. and Srivastava, R.K. 2017. Genetic diversity analysis among inbred lines of pearl millet [Pennisetum glaucum (L.) R. Br.] based on grain yield and yield component characters. Int.J.Curr.Microbiol.App.Sci. 6(6): 22402250.

Rai, K.N., Govindaraj, M. and Rao, A.S. 2012. Genetic enhancement of grain iron and zinc content in pearl millet. Qual Assur Saf Crop., 4:119-125.

Rai, K.N., Velu, G., Govindaraj, M., Upadhyaya, H.D., Rao, A.S., Shivade, H. and Reddy, K.N. 2015. Iniadi pearl millet germplasm as a valuable genetic resource for high grain iron and zinc densities. Plant Genet Resour., 13:75-82.

Rai, K.N., Yadav, O.P., Rajpurohit, B.S., Patil, H.T., Govindaraj, M., Khairwal, I.S., Rao, A.S., Shivade, H., Pawar, V.Y. and Kulkarni, M.P. 2013. Breeding pearl millet cultivars for high iron density with zinc density as an associated trait. J SAT Agric Res., 11:1-7.

R Development Core Team .2017. R: A language and environment for statistical computing. $\mathrm{R}$ Foundation for Statistical Computing, Vienna, Austria. URL https://www.Rproject.org

Sankar, S.M., Satyavathi, C.T., Singh, S.P., Singh, 
M.P., Bharadwaj, C. and Barthakur, S. 2014. Genetic diversity analysis for high temperature stress tolerance in pearl millet [Pennisetum glaucum (L.) R. Br]. Indian J. Plant Physiol., 19(4): 324-329.

Sathya, M., Vinodhana, N.K. and Sumathi, P. 2013. Hierarchial clustering of pearl millet (Pennisetum glaucum (L.) R.Br) inbreds for morpho-physiological traits. Int. J. Curr. Microbiol. App. Sci., 2(12): 647-652.

Sangwan, S., Yashveer, S., Kumar, R., Hemender, Sharma, S. and Redhu, N. 2019. Multiariate analysis reveals substantial diversity in pearl millet [Pennisetum glaucum (L). R. Br.] inbred lines. J. Exp Bio Agric Sci., 7(4): 358-375.

Shanmuganathan, M., Gopalan, A. and Mohanraj, K. 2006. Genetic variability and multivariate analysis in pearl millet (Pennisetum glaucum (L.) R. Br.) germplasm for dual purpose. J. Agric. Sci., 2(1): 73-80.

Shannon, C. E. 1948. A mathematical theory of communication. Bell Syst. Tech. J., 27: 623656.

Sharma, B., Chaugh, L.K., Sheoran, R.K., Singh, V.K., and sood, M. 2018. Study on genetic variability, heritability and correlation in pearl millet germplasm. J Pharmacogn Phytochem., 7(6): 1983-1987.

Singh, D., Chhonkar, P. K. and Dwivedi, B. S. 2005. Manual on Soil, Plant and Water Analysis. New Delhi:Westville Publishing House.

Singh, O.V. and Singh, A.K. 2016. Analysis of genetic variability and correlation among traits in exotic germplasm of pearl millet [Pennisetum glaucum (L.) R. Br.]. Indian J Agric Res., 50(1): 76-79.
Stein, A.G. 2010. Global impacts of human mineral malnutrition. Plant Soil., 335:133154.

Upadhyaya, H.D., Reddy, K.N., Singh, S., Gowda, C..L.L., Ahmed, M.I. and Ramachandran, S. 2013. Latitudinal patterns of diversity in the world collection of pearl millet landraces at the ICRISAT genebank. Plant Genet. Resour, doi: http://dx.doi.org/10.1017/S1479262113000 348.

Velu, G., Rai, K.N. and Sahrawat, K.L. 2008a. Variability for grain iron and zinc content in a diverse range of pearl millet populations. Crop Improvement., 35:186191.

Velu, G., Rai, K.N., Muralidharan, V., Kulkarni, V.N., Longvah, T. and Raveendran, T.S. 2007. Prospects of breeding biofortified pearl millet with high grain iron and zinc content. Plant Breed., 126:182-185.

Velu, G., Rai, K.N., Sahrawat, K.L. and Sumalini, K. 2008b. Variability for grain iron and zinc contents in pearl millet hybrids. $J$ SAT Agric Res., 6:1-4.

Vidhyadhar, B. and Devi, I.S. 2007. Evaluation of germplasm for genetic diversity in pearl millet. J. Res. ANGRAU., 35(1): 119-123.

Welch, R.M. and Graham, R.D. 2004. Breeding for micronutrients in staple food crops from a human nutrition perspective. J Exp Bot., 55:353-364.

World Health Organization. 2002. Genomics and world health: Report of the Advisory Committee on Health Research.

Yadav, O.P. and Rai, K.N. 2013. Genetic improvement of pearl millet in india. Agric Res., 2, 275-292.

\section{How to cite this article:}

Mithlesh Kumar, Kirti Rani, B. C. Ajay, M. S. Patel, K. D. Mungra and Patel. M. P. 2020. Multivariate Diversity Analysis for Grain Micronutrients Concentration, Yield and Agromorphological Traits in Pearl millet (Pennisetum glaucum (L) R. Br.). Int.J.Curr.Microbiol.App.Sci. 9(03): 2209-2226. doi: https://doi.org/10.20546/ijcmas.2020.903.253 